\title{
PERAN OMBUDSMAN REPBULIK INDONESIA DALAM PENYELESAIAN MALADMINISTRASI DI INDONESIA
}

\author{
Enny Agustina \\ Magister Ilmu Hukum Universitas Kader Bangsa \\ Email : ennyagustinadua@yahoo.com
}

Received: - /Revised: - /Accepted: Des 2018

\begin{abstract}
Keberadaan Ombudsman di berbagai negara modern, terutama negara-negara Kesejahteraan (Negara Kesejahteraan) adalah tonggak yang menjadi tumpuan harapan masyarakat atau warga negara untuk membela hak-hak mereka yang dirugikan oleh tindakan pejabat administratif karena keputusan dikeluarkan. Ombudsman diperlukan untuk menangani penyalahgunaan wewenang oleh pejabat pemerintah dan pada saat yang sama membantu aparat negara untuk melaksanakan administrasi negara secara efisien dan adil. Ombudsman akan mendorong pemegang kekuasaan negara untuk menjalankan akuntabilitas dengan benar. Implementasi Undang-undang tentang Ombudsman Republik Indonesia adalah salah satu terobosan revolusioner dan inovatif dalam sistem hukum di Indonesia. Administrator pemerintah yang melakukan tindakan maladministrasi dan direkomendasikan oleh Ombudsman Indonesia wajib menerapkan rekomendasi ini. Ombudsman tidak hanya menjadi institusi pengaruh dalam pelayanan publik (Magistrature of influence), tetapi juga sebagai lembaga yang memberlakukan sanksi (Magistrature of sanction). Seperti dalam pertimbangan UU No. 37 tahun 2008 tentang Ombudsman Republik Indonesia yang menyatakan bahwa pelayanan kepada masyarakat dan penegakan hukum yang dilaksanakan dalam konteks administrasi negara dan pemerintahan merupakan bagian integral dari upaya menciptakan yang baik, bersih dan pemerintahan yang efisien untuk meningkatkan kesejahteraan dan menciptakan keadilan dan kepastian hukum bagi semua warga negara sebagaimana dimaksud dalam Undang-Undang Dasar Negara Republik Indonesia Tahun 1945.
\end{abstract}

Kata Kunci: Administrasi Mal, administrator pemerintah, layanan publik. 


\begin{abstract}
The existence of the Ombudsman in various modern countries, especially countries of Welfare State (Welfare State) was a milestone that was the foundation of the hopes of the community or citizens to defend their rights that are harmed by the actions of administrative officials because of the decisions issued. The Ombudsman was needed to deal with abuse of authority by government officials and at the same time help state apparatus to carry out state administration efficiently and fairly. The Ombudsman will encourage state power holders to carry out accountability properly. The implementation of the Law on the Ombudsman of the Republic of Indonesia was one of the revolutionary and innovative breakthroughs in the legal system in Indonesia. Government administrators who carry out maladministration actions and are recommended by the Indonesian Ombudsman are obliged to implement these recommendations. The Ombudsman wa not only an influence institution in public service (Magistrature of influence), but also as a sanctioning institution (Magistrature of sanction). As in the consideration of Law No. 37 of 2008 concerning the Ombudsman of the Republic of Indonesia which states that service to the community and law enforcement carried out in the context of state administration and government are an integral part of efforts to create good, clean and efficient governance to improve welfare and creating justice and legal certainty for all citizens as referred to in the 1945 Constitution of the Republic of Indonesia.
\end{abstract}

Keywords : Mal administration, government administrators, public services.

\title{
PENDAHULUAN
}

\section{LATAR BELAKANG}

Tujuan pemerintah negara bagian umumnya didasarkan pada citacita atau tujuan negara. Sedangkan tujuan dari administrasi negara Indonesia seperti pada pembukaan keempat UndangUndang Dasar Negara Republik Indonesia adalah untuk melindungi seluruh bangsa Indonesia dan semua pertumpahan 
darah, untuk memajukan kesejahteraan publik, mendidik kehidupan bangsa, dan berpartisipasi dalam membawa keluar tatanan dunia berdasarkan kebebasan, perdamaian abadi dan keadilan sosial. Lembaga-lembaga dalam satu sistem pemerintahan Indonesia bekerja bersama dan saling mendukung untuk perwujudan tujuan pemerintah di Indonesia. Salah satu karakteristik utama dari negara kesejahteraan adalah kewenangan yang luas bagi pemerintah untuk menjalankan fungsifungsi pemerintah dalam rangka mewujudkan kesejahteraan masyarakat, elemen pengawasan menjadi elemen yang sangat penting untuk mencegah interaksi negatif antara pemerintah dan rakyatnya, sebagai akibat dari maladministrasi terkait dengan tingkat kewenangan Pemerintah. Keberadaan Ombudsman di berbagai negara modern, terutama negara-negara Kesejahteraan Negara , merupakan tonggak yang menjadi tumpuan harapan masyarakat atau warga negara untuk membela hak-hak mereka yang dirugikan oleh tindakan pejabat administratif karena keputusan mereka .

Fungsi Ombudsman di Indonesia tidak jauh berbeda dengan Ombudsman di banyak negara, yaitu: (1) mengakomodasi partisipasi publik dalam upaya untuk mendapatkan layanan publik yang berkualitas dan efisien, administrasi yudisial yang 


\section{Enny Agustina}

adil, tidak memihak dan jujur; (2) meningkatkan perlindungan individu dalam memperoleh layanan publik, keadilan, kesejahteraan dan dalam mempertahankan hak mereka terhadap penyimpangan dalam tindakan penyalahgunaan wewenang (penyalahgunaan kekuasaan), penundaan yang berlarut-larut (penundaan yang tidak semestinya), dan kebijaksanaan yang tidak benar. ${ }^{1}$ Di banyak negara, ombudsman telah menjadi lembaga alternatif bagi warga untuk menyelesaikan keluhan atau ketidakpuasan terhadap birokrasi pemerintah dengan cepat, gratis, tidak perlu membayar pengacara dan aman (kerahasiaan pelapor yang dilindungi). Penyelesaian melalui lembaga-lembaga peradilan untuk masalah-masalah maladministrasi sebagian besar telah ditinggalkan karena sangat lambat, mahal dan jauh dari non-user friendly.

Tantangan terbesar yang dihadapi oleh Indonesia saat ini adalah bagaimana membangun kredibilitas sehingga mayoritas orang mematuhi dan bekerja sama dengan pemerintah. Kredibilitas dapat diproses dan dikembangkan melalui program yang memberikan kesejahteraan bagi banyak orang, atau dengan memberikan layanan terbaik kepada masyarakat. Masyarakat juga memiliki peran dalam proses membangun penegakan hukum

\footnotetext{
${ }^{1}$ dkk , Hesti Puspitosari. 2011, Filosofi Pelayanan Publik, Malang : setara Pers.
} 
untuk mendapatkan keadilan, karena mereka adalah bagian, dan juga target, keadilan itu sendiri. Masyarakat adalah komponen yang seharusnya merasakan keadilan, dan bukan sebaliknya, menjadi obyek dan korban ketidakadilan. Sehingga individu, terutama kelompok rendah dan miskin, terus menerus tidak menjadi korban penyalahgunaan wewenang, komunitas itu sendiri harus memiliki tempat untuk melakukan pengawasan. Kami sudah tahu lembaga pengawas sebagai Ombudsman. Masyarakat berhak melakukan pengawasan karena administrasi pemerintahan dan administrasi negara pada dasarnya didasarkan pada mandat yang diberikan oleh rakyat melalui pemilihan umum. Pengawasan oleh Ombudsman adalah pengawasan nyata, yaitu pengawasan untuk mendapatkan layanan terbaik dari administrator pemerintah.

\section{PERMASALAHAN}

1. Apa Peran Ombudsman Indonesia dalam Menangani Maladministrasi?

\section{TUJUAN PENELITIAN}

a. Untuk Mengetahui Peran Ombudsman Dalam Menangani Maladministrasi Di Indonesia. 
b. Untuk Menganalisis Peran Serta Bentuk Yang Dilakukan Ombudsman Dalam Mengatasi Maladministrasi Yang Dilakukan Oleh Administrator Di Indonesia.

\section{MANFAAT PENELITIAN}

a. Untuk Mengetahui Peran Ombudsman Dalam Menangani Maladministrasi Di Indonesia.

\section{METODE PENELITIAN}

Metode pengumpulan data yang kami gunakan untuk menunjang dan memperkaya penelitian ini adalah dengan :

\section{Metode Pendekatan}

Metode pendekatan yang kami gunakan ialah metode pendekatan konseptual ${ }^{2}$. Pendekatan ini beranjak dari pandangan pandangan dan doktrin yang berkembang di dalam ilmu hukum.

\section{Sumber Data}

Penelitian hukum yang bersifat normatif selalu menitikberatkan pada data sekunder. Data sekunder pada penelitian dapat dibedakan menjadi :

a. Bahan Hukum Primer, berupa perundang- undangan UU No. 37 tahun 2008 tentang Ombudsman Republik Indonesia, UU No. 25 tahun 2009 tentang Pelayanan Publik.

b. Bahan Hukum Sekunder, berupa pendapat hukum/ doktrin/ teori-teori yang diperoleh dari literatur hukum, artikel ilmiah, maupun website.

2 Johnny Ibrahim, 2006, Metodologi Penelitian Hukum Normatif, Malang: Banyumedia Publishing 
c. Bahan Hukum Tersier, berupa kamus terjemahan, kamus black law, kamus wikipedia.

\section{Metode Pengumpulan Data}

Dalam penulisan Penelitian ini, penulis menggunakan teknik pengumpulan data yaitu melalui Penelitian Studi Dokumen yaitu pengumupulan data yang tidak ditujukan langsung kepada subjek penelitian.

\section{PEMBAHASAN}

1. Peran Ombudsman Dalam Menangani Maladministrasi Di Indonesia.

Secara umum ombudsman dikenal sebagai lembaga independen yang menerima dan menyelidiki keluhan orang-orang yang menjadi korban kesalahan administrasi publik. Itu termasuk keputusan atau tindakan pejabat publik yang tidak pantas, menyimpang, sewenang-wenang (tidak teratur / tidak sah), penyalahgunaan kekuasaan, ${ }^{3}$ penundaan yang tidak perlu (penundaan yang tidak semestinya) atau pelanggaran kepemilikan. Pembentukan Ombudsman dimotivasi oleh beberapa alasan:

1) Fungsi dan tugas penyelenggaraan negara pada intinya adalah mewujudkan kemakmuran bagi masyarakat.

2) Komunitas memiliki hak untuk mendapatkan layanan yang sama dan adil oleh administrator negara.

3) Dalam prakteknya, ada banyak penyimpangan; penyelenggara negara tidak melayani tetapi meminta untuk

${ }^{3}$ Hamidi, Jazim, 2009, Penerapan asas-asas umum penyelenggaraan pemerintahan yang layak (AAUPL) dilingkungan Peradilan Administrasi Indonesia (Upaya Menuju Clean And Stable Government), Cetakan ke III, Bandung: Citra Aditya Bakti. 
dilayani, orang menjadi benda / menjadi korban / menjadi pembantu pejabat negara; tidak ada ukuran standar pemberian layanan.

4) Pelaksanaan layanan oleh negara harus dimonitor karena banyaknya ketidakberesan, juga untuk mencegah penyimpangan. Dengan demikian, konsep Ombudsman pada dasarnya adalah untuk mengawasi penyediaan layanan yang disediakan oleh administrator negara; secara langsung atau tidak langsung akan berdampak pada upaya pemberantasan KKN.

Konsep Ombudsman memandang korupsi lebih luas, yaitu tidak hanya dari aspek hukum tetapi aspek sosiologis yaitu semua bentuk perilaku koruptif. Dalam perkembangan terakhir, konsep Ombudsman telah didasarkan pada UU No. 37 tahun 2008 tentang Ombudsman Republik Indonesia dan bahkan diperkuat oleh UU No. 25 tahun 2009 tentang Pelayanan Publik.

Ombudsman diperlukan untuk menangani penyalahgunaan wewenang oleh pejabat pemerintah dan pada saat yang sama membantu aparat negara untuk melaksanakan administrasi negara secara efisien dan adil. Ombudsman akan mendorong pemegang kekuasaan negara untuk menjalankan akuntabilitas dengan benar.

Beberapa alasan mendasar mengapa banyak negara, termasuk Indonesia, membentuk Ombudsman Institute:

1) Ombudsman Secara Institusional Independen baik struktural, fungsional dan pribadi. Sifat independen ini akan sangat mempengaruhi efektivitasnya karena dalam bertindak selalu objektif, adil, dan tidak memihak. 
2) Tujuan pengawasan adalah pemberian layanan. Ini berarti bahwa dalam bertindak, aparat menjadi pelayan sehingga warga diperlakukan sebagai subyek, bukan objek / korban layanan.

3) Prosedur atau mekanisme yang digunakan dalam proses pengawasan tidak rumit dan juga dimungkinkan untuk proses penyelesaian melalui mediasi dengan prinsip saling menang-menang.

4) Ombudsman Institute secara tegas dan terbuka menyatakan bahwa pengawasan yang dilakukan atau laporan yang ditindaklanjuti tidak dikenakan biaya.

5) Ombudsman juga menganut prinsip bahwa dalam menyelesaikan laporan selalu mendengarkan dua pihak karena tidak melayani surat kaleng.

Konsep lembaga Ombudsman berdasarkan Undang-undang No. 37 tahun 2008 tentang Ombudsman Indonesia dan berdasarkan UU No. 25 tahun 2009 tentang layanan publik, ternyata sangat akomodatif terhadap partisipasi masyarakat, dengan memberikan peran yang menyeimbangkan pemerintah yang memiliki kewajiban untuk menyediakan layanan dengan komunitas yang memiliki hak untuk mendapatkan layanan. Dalam UU Layanan Publik dinyatakan bahwa ombudsman RI. dan masyarakat adalah pengawas eksternal selain DPR / DPRD dalam hal maladministrasi dalam administrasi pelayanan publik oleh pejabat pemerintah. Hal ini sebagaimana tercantum dalam Pasal 35 ayat 3 UU No. 25 tahun 2009 tentang Pelayanan Publik: "pengawasan eksternal terhadap pelaksanaan layanan publik dilakukan melalui":

a. Sebuah. pengawasan oleh publik dalam bentuk laporan atau pengaduan masyarakat dalam pelaksanaan layanan publik; 
b. pengawasan oleh ombudsman sesuai dengan hukum dan peraturan

c. pengawasan oleh dewan perwakilan rakyat, legislatif provinsi, legislatif kabupaten / kota.

Berdasarkan artikel di atas, partisipasi masyarakat dalam implementasi layanan publik dapat dimulai dari persiapan standar layanan hingga evaluasi dan pemberian penghargaan. Partisipasi masyarakat diwujudkan dalam bentuk kerjasama dalam memenuhi hak dan kewajiban masyarakat dan peran aktif dalam penyusunan kebijakan pelayanan publik dan masyarakat dapat membentuk badan pengawasan layanan publik.

Komunitas memiliki hak untuk mengeluh tentang layanan publik kepada Ombudsman. Petugas yang melakukan pelanggaran atau penyimpangan, orang yang bersangkutan dapat dikenakan sanksi dalam bentuk pembebasan dari kantor, penurunan pangkat atau sanksi administrasi lainnya. Jika itu melanggar ketentuan pidana, itu dapat dituntut untuk hukuman fisik atau kompensasi. Sehubungan dengan konteks upaya pemberantasan korupsi di Indonesia, Antonius Sujata menyatakan bahwa posisi Ombudsman lebih di garda depan untuk mencegah terjadinya tindakan administratif dan perilaku korup dari semua pejabat pemerintah. Pendapat ini dibangun di atas asumsi bahwa sistem pelayanan publik tidak berjalan dengan baik karena penuh dengan tindakantindakan maladministratif dan praktik-praktik organizer yang 
korup. Dengan demikian, posisi Ombudsman bukan hanya lembaga pengawas yang lebih bersifat preventif 6 tetapi berdasarkan pasal 38 Undang-undang No. 37 tahun 2008 tentang Ombudsman Indonesia, mengenai kewajiban untuk melaksanakan rekomendasi untuk pihak yang dilaporkan dan melaporkan atasan, peran ombudsman juga bersifat represif.

Implementasi Undang-undang tentang Ombudsman Republik Indonesia dan juga Undang-Undang Pelayanan Publik adalah salah satu terobosan revolusioner dan inovatif dalam sistem hukum di Indonesia. Administrator pemerintah yang melakukan tindakan maladministrasi dan direkomendasikan oleh Ombudsman Indonesia wajib menerapkan rekomendasi ini. Dengan kata lain, Ombudsman bukan hanya lembaga pengaruh dalam pelayanan publik (Magistrature of influence), tetapi juga sebagai lembaga yang memberlakukan sanksi (Magistrature of sanction). ${ }^{4}$ Sebagaimana dalam pertimbangan UU No. 37 tahun 2008 tentang Ombudsman Republik Indonesia yang menyatakan bahwa pelayanan publik dan penegakan hukum dilakukan dalam rangka penyelenggaraan negara dan pemerintahan merupakan bagian yang tidak terpisahkan dari upaya menciptakan pemerintahan yang baik, bersih dan efisien dalam rangka meningkatkan

${ }^{4}$ K. C. Wheare, 1973, Maladministration and its Remedies, First Edition London: Steven and Son. 


\section{Enny Agustina}

kesejahteraan dan menciptakan keadilan dan kepastian hukum bagi semua warga negara sebagaimana dimaksud dalam UndangUndang Dasar Negara Republik Indonesia Tahun 1945. ${ }^{5}$

Selain itu, pengawasan layanan yang diselenggarakan oleh administrator pemerintah merupakan elemen penting dalam upaya menciptakan tata kelola yang baik, bersih dan efisien dan pada saat yang sama merupakan implementasi dari prinsip-prinsip demokrasi yang perlu dikembangkan dan diterapkan untuk mencegah dan menghilangkan penyalahgunaan otoritas oleh pejabat pemerintah. Kemudian sebuah lembaga dibentuk yang mengawasi administrasi pemerintahan yang menjamin pelaksanaan layanan publik maksimum dan untuk mewujudkan pemerintahan yang baik, bersih dan efisien. Dengan berlakunya undang-undang ini, Ombudsman Nasional harus dapat memainkan peran untuk mendorong terciptanya penyampaian layanan publik yang maksimal, dalam rangka menciptakan pemerintahan yang baik dan bersih, dan untuk mencegah terjadinya tindakantindakan maladministrasi yang merugikan penduduk. Indonesia, baik material maupun immaterial. Pandangan lain mengenai tujuan keberadaan Ombudsman RI adalah sebagaimana yang dinyatakan oleh HA Kurdi Moekri dari Fraksi PPP menyatakan

${ }^{5}$ UU No. 37 tahun 2008 tentang Ombudsman Republik Indonesia 
bahwa: praktik-praktik maladministratif yang terstruktur dan berjalan lama telah menjadi sub-budaya di dalam birokrasi pemerintah negara yang sulit dihilangkan hingga sekarang. Ungkapan "jika masih bisa rumit untuk apa yang dibuat lebih mudah". Sebagai akibat dari praktik birokrasi ini, dapat dipastikan bahwa hak warga atas infrastruktur berkualitas dan layanan publik yang berkualitas sangat sulit untuk direalisasikan. Ini juga karena kurangnya standarisasi layanan publik yang menjadi acua bagi semua badan layanan publik. Oleh karena itu, upaya reformasi birokrasi dan administrasi negara yang bersih dan bebas dari pemerintah KKN adalah suatu keharusan dengan meningkatkan kualitas penyelenggara negara dan penegakan prinsip-prinsip good governance. Terlepas dari hal-hal yang tidak kurang penting, perlu memiliki lembaga eksternal yang dapat secara efektif mengawasi tugas-tugas para administrator negara dan pemerintah. Dengan demikian diharapkan dapat meningkatkan kualitas layanan publik secara lebih terukur.

Berdasarkan Undang-undang No. 37 tahun 2008, Ombudsman Republik Indonesia adalah lembaga negara yang independen dan tidak memiliki hubungan organik dengan lembaga negara dan lembaga pemerintah lainnya, dan dalam melaksanakan tugas dan wewenangnya bebas dari campur tangan dari kekuatan lain . 
Keberadaan Ombudsman Republik Indonesia berdasarkan pasal 1 ayat (1) UU No. 37 tahun 2008 tentang Ombudsman Republik Indonesia adalah: Lembaga negara yang memiliki kewenangan untuk mengawasi pelaksanaan pelayanan publik yang baik dipegang oleh administrator negara dan pemerintah termasuk yang dimiliki oleh Badan Usaha Milik Negara, Badan Usaha Milik Daerah, dan Badan Hukum Milik Negara serta badan-badan swasta atau perorangan yang diberi tugas melaksanakan layanan publik tertentu yang sebagian atau seluruhnya bersumber dari anggaran negara dan / atau anggaran pendapatan dan belanja daerah.

Mengenai keberadaan Ombudsman Republik Indonesia di atas, yayasan bertumpu pada Ombudsman Indonesia harus sesuai dan sejalan dengan tujuan Ombudsman RI itu sendiri. Tujuan Ombudsman Indonesia didirikan dengan tujuan sebagaimana dalam Pasal 4 UU No. 37 tahun 2008 dengan jelas menguraikan tujuan Ombudsman, yaitu:

a. Sebuah. Mewujudkan negara hukum yang demokratis, adil dan makmur;

b. Mendorong administrasi negara dan pemerintahan yang efektif dan efisien, jujur, terbuka, bersih dan bebas dari korupsi, kolusi dan nepotisme

c. Meningkatkan kualitas layanan negara di semua bidang sehingga setiap warga negara dan penduduk dapat 
memperoleh keadilan, keamanan, dan kemakmuran yang lebih baik;

d. Membantu menciptakan dan meningkatkan upaya-upaya untuk memberantas dan mencegah praktik-praktik maladministrasi, diskriminasi, korupsi, kolusi, dan nepotisme;

e. Meningkatkan budaya hukum nasional, kesadaran hukum publik, serta

f. Supremasi hukum yang memiliki esensi kebenaran dan keadilan.

Pengaruh Ombudsman masuk melalui rekomendasi yang disiapkan dan diberikan kepada Organisasi Negara dan pemerintah, meskipun rekomendasi Ombudsman tidak mengikat secara hukum, itu tidak berarti bahwa mereka dapat diabaikan. Dalam hal ini Ombudsman memiliki mekanisme pelaporan ke DPR. ${ }^{6}$ Untuk kasus-kasus tertentu yang signifikan dan krusial, melalui mekanisme yang tersedia, DPR juga dapat memanggil pejabat publik (eksekutif) karena mereka mengabaikan keberadaan dan rekomendasi dari Ombudsman. Namun dalam praktik di masa lalu, tidak sedikit rekomendasi KON yang dikesampingkan atau bahkan dipinggirkan.

Jadi berdasarkan Undang-undang No. 37 tahun 2008, rekomendasi Ombudsman sebelumnya tidak mengikat, sekarang rekomendasi

${ }^{6}$ M. Hadjon , Philipus, 1987, Perlindungan Hukum Bagi Rakyat di Indonesia, Surabaya : Bina Ilmu. 
harus dilaksanakan. Ini sebagaimana diatur dalam pasal $38 \mathrm{UU}$ No. 37 tahun 2008 yang menyatakan bahwa:

a. Sebuah. Terlapor dan atasan Terlapor wajib melaksanakan Rekomendasi Ombudsman.

b. Terlapor wajib menyampaikan laporan kepada Ombudsman mengenai pelaksanaan Rekomendasi yang telah dilakukan bersama dengan hasil pemeriksaan dalam waktu 60 (enam puluh) hari sejak tanggal diterimanya Rekomendasi.

c. Ombudsman dapat meminta informasi dari Terlapor dan / atau

d. supervisor dan melakukan pemeriksaan lapangan untuk memastikan pelaksanaan Rekomendasi.

e. Dalam hal Terlapor dan atasan Terlapor tidak mengimplementasikannya Rekomendasi atau menerapkan beberapa Rekomendasi untuk alasan yang tidak dapat diterima oleh Ombudsman, Ombudsman dapat mempublikasikan atasan Terlapor yang tidak mengimplementasikan Rekomendasi dan menyerahkan melapor ke DPR dan Presiden.

\section{PENUTUP}

Ombusdman adalah sebuah lembaga yang bukan hanya Penguasa Pengaruh, yang memiliki kewenangan untuk mengikat secara moral (Pengikatan moral), tetapi juga memiliki wewenang untuk menjatuhkan sanksi (Magistrate of Sancsion) di mana rekomendasinya mengikat dan harus dilaksanakan (Pengikatan Hukum)). Ini berarti bahwa setiap agen menjadi pihak yang dilaporkan dan atasan yang dilaporkan jika terbukti telah melakukan maladministrasi dalam administrasi pemerintah, wajib melaksanakan rekomendasi dari Ombudsman RI. Jika sanksi tidak 
diterapkan maka sanksi administratif akan dikenakan sesuai dengan hukum dan peraturan yang berlaku. Hal ini sebagaimana tercantum dalam Pasal 39 UU No. 37 tahun 2008 tentang Ombudsman Republik Indonesia.

\section{KESIMPULAN}

Fungsi dan tugas penyelenggaraan negara pada intinya adalah mewujudkan kemakmuran bagi masyarakat. Komunitas memiliki hak untuk mendapatkan layanan yang sama dan adil oleh administrator negara. Dalam prakteknya, ada banyak penyimpangan; penyelenggara negara tidak melayani tetapi meminta untuk dilayani, orang menjadi benda / menjadi korban / menjadi pembantu pejabat negara; tidak ada ukuran standar pemberian layanan. Pelaksanaan layanan oleh negara harus dimonitor karena banyaknya ketidakberesan, juga untuk mencegah penyimpangan. Dengan demikian, konsep Ombudsman pada dasarnya adalah untuk mengawasi penyediaan layanan yang disediakan oleh administrator negara; secara langsung atau tidak langsung akan berdampak pada upaya pemberantasan KKN.

\section{SARAN}

Harus ada standar pelayanan yang pasti sehingga tidak ada lagi penyimpangan dan pelaksanaan pelayanan harus di monitoring supaya tidak ada ketidakberesan dalam pemberian layanan.

\section{DAFTAR PUSTAKA}

Hesti Puspitosari dkk. 2011, Filosofi Pelayanan Publik, Malang, setara Pers. 
H. Amrah Musilmin,1985, Beberap Asas dan Pengertian Pokok Tentang Administrasi dan Hukum administrasi, Bandung: Alumni.

INDEF, 1999, Birokrasi, Korupsi dan Reformasi, Kasus Pelayanan KTP, Jakarta, INDEF.

Jazim Hamidi,1999, Penerapan asas-asas umum penyelenggaraan pemerintahan yang layak (AAUPL) dilingkungan Peradilan Administrasi Indonesia (Upaya Menuju Clean And Stable Government), Cetakan ke I, Bandung: Citra Aditya Bakti.

Johnny Ibrahim, 2006, Metodologi Penelitian Hukum Normatif, Malang: Banyumedia Publishing.

K. C. Wheare, 1973, Maladministration and its Remedies, First Edition London: Steven and Son.

Kuntjoro Purbopranoto, 1981, Beberapa catatan Hukum tata pemerintahan dan peradilan Administrasi negara, Bandung; Alumni.

Moh. Mahfud MD, 2000, Pemerintahan Yang Bersih Perspektif Politik, Hukum, Ekonomi, Budaya dan Agama, Yogyakarta, Ull Press.

Philipus M. Hadjon, 1987, Perlindungan Hukum Bagi Rakyat di Indonesia, Surabaya, Bina Ilmu.

\section{Undang-Undang :}

Undang Undang No. 37 tahun 2008 tentang Ombudsman Republik Indonesia

Undang Undang No. a. No. 25 tahun 2009 tentang Pelayanan Publik. 